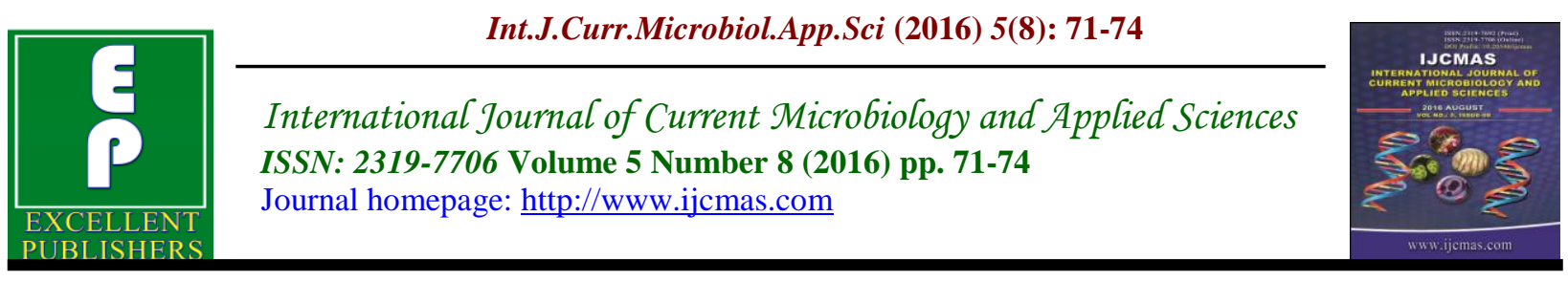

Original Research Article

http://dx.doi.org/10.20546/ijcmas.2016.508.008

\title{
Prevalence of Rotavirus Diarrhoea in Children Below 5 Years, A Pilot Study
}

\author{
P. Jyothi *, K. Prasanthi and P. Kamala \\ Department of Microbiology, Guntur Medical College / Hospital, \\ Guntur, Andhra Pradesh, Pin-522004, India \\ *Corresponding author
}

\begin{tabular}{|c|c|}
\hline & A B S T R A C T \\
\hline $\begin{array}{l}\text { Rotavirus, } \\
\text { Diarrhoea, } \\
\text { watery stool, } \\
\text { ELISA, } \\
\text { Antigen } \\
\text { detection, } \\
\text { Gastroenteritis. }\end{array}$ & \multirow{3}{*}{$\begin{array}{l}\text { Rotavirus is a leading cause of severe acute gastroenteritis requiring hospitalization } \\
\text { among infants and young children worldwide. Data on rotavirus disease burden are } \\
\text { needed across India to support credible, evidence-based decisions regarding any } \\
\text { intervention. This pilot study was taken up to estimate the prevalence of rotavirus } \\
\text { diarrhoea in children younger than } 5 \text { years of age in a tertiary health care setting. } \\
\text { Stool specimens were collected from children aged less than } 5 \text { years suffering from } \\
\text { acute watery diarrhoea admitted in the paediatric ward Guntur medical college } \\
\text { hospital, Guntur and rotavirus antigen was detected in stool samples by Enzyme } \\
\text { Immunoassay. Out of } 44 \text { stool specimens tested, rotavirus was detected in } 11 \text { ( } 25 \% \text { ) } \\
\text { samples. High prevalence of rotavirus diarrhoea was seen in children aged } 6 \\
\text { months to } 11 \text { months } 36.4 \% \text { followed by } 12 \text { months to } 23 \text { months } 27.3 \% \text {. Among } \\
\text { rotavirus positive children } 72.7 \% \text { were males and } 27.3 \% \text { were females. Hence } \\
\text { rotavirus diarrhoea accounts for a large proportion of diarrheal disease in } \\
\text { hospitalized children less than } 5 \text { years. }\end{array}$} \\
\hline Art & \\
\hline $\begin{array}{l}\text { Accepted: } \\
\text { 06 July } 2016 \\
\text { Available Online: } \\
\text { 10 August } 2016\end{array}$ & \\
\hline
\end{tabular}

\section{Introduction}

Diarrheal diseases are a major cause of hospitalizations and child deaths globally. Together they account for approximately one in six deaths among children younger than five years (Shaun Morris et al., 2012). Rotavirus is the leading cause of diarrhoea hospitalization among children worldwide (Umesh Parashar et al., 2006; Mathew et al., 2014; Kahn et al., 2012). Studies in the last decade estimate the annual mortality due to rotavirus in India to be between 90,000 and 153,000 (Jacob John et al., 2014). Rotavirus infection ranges from asymptomatic infection to severe life threatening diarrhoea. It has been estimated that $29 \%$ of all diarrheal deaths in children $<5$ years of age is due to rotavirus and about $23 \%$ of rotavirus deaths are in the Indian subcontinent. Rotavirus infection affects $95 \%$ of children under the age of 5 years regardless of the socio-economic or environmental conditions and leads more frequently to dehydration than other aetiologies (John et al., 2014). Improved treatment using oral rehydration solution and diarrhoea control measures, such as sanitation and water purification, have been effective strategies to reduce diarrhoeaassociated mortality over the past 2 decades. However, interventions that prevent 
diarrhoea associated with some bacterial and parasitic agents are less effective against rotavirus diarrhoea. Consequently, the World Health Organization (WHO) and others have recommended rotavirus vaccines as the most effective strategy to prevent rotavirus-related morbidity and mortality (Mark Malek et al., 2010).

There are limited data on rotavirus disease burden among children in Andhra Pradesh and there is a need for data on prevalence of rotavirus diarrhea especially in our setting. So we conducted a pilot study in our Guntur medical college / hospital which is a tertiary care hospital with the objective to estimate the prevalence of diarrhoea due to rotavirus among hospitalized children younger than 5 years of age.

\section{Materials and Methods}

This was a pilot study carried over a period of 4 months from January to April 2015 at clinical microbiology lab, Guntur medical college / hospital, Guntur, Andhra Pradesh, India. Informed consent was taken from parents/guardians. Study was approved by institution ethics committee.

All children aged less than 5 years suffering from acute diarrhoea admitted in the paediatric ward were included in the study. Children above 5 years, children with dysentery and chronic diarrhoeas were excluded. Demographic data was collected in a prescribed proforma. Stool specimens were collected from hospitalized children and stored in the refrigerator at $4{ }^{\circ} \mathrm{C}$ and later transported to the laboratory in icebox and stored at $-20^{\circ} \mathrm{C}$ in the testing laboratory. Rotavirus antigen was detected in stool samples by Enzyme Immunoassay (Premier
Rotaclone) which utilizes monoclonal antibodies in a solid phase sandwich type EIA which was highly sensitive $(100 \%)$ and specific $(97 \%)$ for rotavirus antigen.

\section{Results and Discussion}

During the study period a total of 44 children below 5 years of age with acute diarrhoea admitted in the hospital were included and had a stool specimen collected for rotavirus antigen testing and most of the children 28(63.6\%) were males and $16(36.4 \%)$ were females (Table I). Age wise distribution of patients showed maximum number of patients in age group of 6 months to 23 months $28(63.6 \%)$.

Of the 44 stool specimens tested, rotavirus was detected in $11(25 \%)$ samples. High prevalence of rotavirus diarrhoea was seen in children aged 6 months to 11 months $4((36.4 \%)$ followed by 12 months to 23 months $3(27.3 \%)$. Low prevalence was seen in children less than 5 months of age and in children between 36 months to 59 months $1(18.2 \%)$ (Table II). Out of 11 positive cases $8(72.7 \%)$ were males and $3(27.3 \%)$ were females. There was no mortality in the study population.

Rotavirus infection has a worldwide distribution and is the single most important cause of gastroenteritis in young children. The virus mainly spreads via the feco-oral route, through respiratory route, person-toperson contact, or contaminated environmental surfaces and fomites. Symptomatic infections are most common in children between the ages of 6 months to 2 yr with a peak incidence at 9-12 months. Males are more frequently affected than females (Shobha Broor et al., 2003). 
Table.1 Gender wise distribution of cases presenting with diarrhoea and rotavirus positivity

\begin{tabular}{|l|c|c|c|}
\hline Gender & Positive & Negative & Total \\
\hline Female & 3 & 13 & 16 \\
\hline Male & 8 & 20 & 28 \\
\hline Total & 11 & 33 & 44 \\
\hline
\end{tabular}

Table.2 Age wise distribution of cases presenting with diarrhea and rotavirus positivity

\begin{tabular}{|l|c|c|c|}
\hline \multirow{2}{*}{$\begin{array}{c}\text { Age group } \\
\text { (in Months) }\end{array}$} & \multicolumn{2}{|c|}{$\begin{array}{c}\text { Enzyme Immunoassay for } \\
\text { Rotavirus }\end{array}$} & \multirow{2}{*}{ Total } \\
\cline { 2 - 3 } & Negative & Positive & \\
\hline $0-5$ & 7 & 1 & 8 \\
\hline $6-11$ & 13 & 4 & 17 \\
\hline $12-23$ & 8 & 3 & 11 \\
\hline $24-35$ & 4 & 2 & 6 \\
\hline $36-59$ & 1 & 1 & 2 \\
\hline Total & 33 & 11 & 44 \\
\hline
\end{tabular}

This was a pilot study to assess the prevalence of rotavirus diarrhoea among children younger than 5 years of age in Guntur, Andhra Pradesh. In this study, rotavirus was detected in $25 \%$ of diarrhoea related hospital admissions among children less than 5 years of age.

Similar results $25.67 \%$ were reported by Manohar Badur et al., (2015) for rotavirus by ELISA. In the study conducted by B.M. John et al., (2014) $24 \%$ were found to be positive for rotavirus antigen in their stool samples. Saravanan et al., (2004) from Chennai reported $22.6 \%$ positivity was associated with Rotavirus diarrhoea. Rotavirus accounts for close to $40 \%$ of hospitalizations for diarrhoea in India by $\mathrm{G}$ Kahn et al., (2012). In the present study most of the Rotavirus diarrhoea cases $(63.6 \%)$ occurred during the first 2 years of life, peaking at 6-11 months age. Similar result was found by Rajiv Bahl et al., (2005) from New Delhi.

Preponderance of infection observed in male children (72.7\%) in our study. Kelkar et al., (1999) from Pune also reported male preponderance of rotavirus diarrhoea. Sex wise incidence of rotavirus infection among male and female was $68 \%$ and $32 \%$ respectively by (Nilesh Shyam Chavan et al., 2014). However no predilection of infection was seen among sex of the patients analysed by Saravanan et al., (2004) from Chennai.

In conclusion, this study highlights that rotavirus diarrhoea accounts for a large proportion of diarrheal disease in hospitalized children less than 5 years in Guntur district, Andhra Pradesh and this high prevalence of rotavirus diarrhoea requiring patient hospitalisation confirms the immense importance of rotavirus diarrhoea with regard to public health.

As this study is pilot study, further study is required to assess the prevalence of rotavirus diarrhoea. The incidence of the disease could not be calculated in this study. 


\section{References}

Jacob John, Rajiv Sarkar, Jayaprakash Muliyil, Nita Bhandari, Maharaj K.Bhan, Gagandeep Kang. 2014. Rotavirus gastroenteritis in India, 2011-2013: Revised estimates of disease burden and potential impact of vaccines. Vaccine Volume 32, Supplement 1, 11 August, Pages A5-A9.

John, B.M., Wg Cdr, Amit Devgan Col, Barnali Mitra Maj. 2014. Prevalence of rotavirus infection in children below two years presenting with diarrhea. Med. J., Armed Forces India. 70(2): 116-119. Published online 2014 Apr 3. doi: 10.1016/j.mjafi.2014.02.008

Kahn, G., Fitzwater, S., Tate, J., Kang, G., Ganguly, N., Nair, G., et al. 2012. Epidemiology and Prospects for Prevention of Rotavirus Disease in India. Review article Indian Pediatr., 49: 467-474.

Kelkar, S.D., Purohit, S.G., Simha, K.V. 1999. Prevalence of rotavirus diarrhoea among hospitalized children in Pune, India. Indian J. Med. Res., 109: 131-135.

Manohar Badur, Naramalli Madhavi Latha, Panabaka Ravi Kumar, Shankar Reddy Dudala, Shabbir Ali Shaik, Gagandeep Kang. et al. 2015. Prevalence of Rotavirus diarrhea among under-5 hospitalized children in a Government tertiary hospital, Tirupati. jdrntruhs Volume : 4 | Issue : 2 | Page :112116.

Availablefrom:http://www.jdrntruhs.org/arti cle.asp?issn $=2277$ -

8632; year $=2015$; volume $=4 ;$ issue $=2 ;$ spage $=1$ 12; ; page $=116$; aulast $=$ Badur

Mark, A., Malek, Nadia Teleb, Remon AbuElyazeed, Mark S. Riddle, May El Sherif, A. Duncan Steele. et al. 2010. The Epidemiology of Rotavirus Diarrhea in Countries in the Eastern Mediterranean
Region. J. Infect. Dis., 202 (Supplement 1): S12-S22 doi:10.1086/653579

Mathew, M.A., Abraham Paulose, S., Chitralekha, M.K.C. Nair, Gagandeep Kang and Paul Kilgore. 2014. Prevalence of Rotavirus Diarrhea among Hospitalized Under-five Children. Res. Paper Indian Pediatr., 51: 27-31.

Nilesh Shyam Chavan and Nilima Tankhiwale. 2014. Detection of human Rotavirus and Bacterial Enteropathogen in Acute Gastroenteritis in children below 5 years of age in Wardha. Int. J. Curr. Microbiol. App. Sci., 3(6): 288-291.

Rajiv Bahl, Pratima Ray, Swati Subodh, Prashant Shambharkar, Manju Saxena, Umesh Parashar. et al. 2005. Incidence of Severe Rotavirus Diarrhea in New Delhi, India, and $G$ and $P$ Types of the Infecting Rotavirus Strains. J. Inf. Dis., Volume 192, Issue Supplement 1Pp. S114-S119.

Saravanan, P., Ananthan, S., Ananthasubramanian, M. 2004. Rotavirus infection among infants and young children in Chennai, South India. ijmmYear: Volume : 22 | Issue : 4 | Page : 212-221

Shaun, K., Morris, Shally Awasthi, Ajay Khera, Diego, G., Bassani, Gagandeep, Kang, Umesh, D., Parashar, et al. 2012. Bulletin of the World Health Organization; 90:720727.doi:10.2471/BLT.12.101873.

Availablefrom:http://www.who.int/bulletin/ volumes/90/10/12-101873/en/. Accessed on 15.2.2015

Shobha Broor, Dhrubaa Ghosh \& Purva Mathur. 2003. Molecular epidemiology of rotaviruses in India. Review Article Indian J. Med. Res., 118, pp 59-67.

Umesh, D., Parashar, Christopher, J., Gibson, Joseph, S., Bresee, Roger, I., Glass. 2006. Rotavirus and severe childhood diarrhea. Emerg. Infect. Dis., 12, pp. 304-306.

\section{How to cite this article:}

Jyothi, P., K. Prasanthi and Kamala, P. 2016. Prevalence of Rotavirus Diarrhoea in Children Below 5 Years, A Pilot Study. Int.J.Curr.Microbiol.App.Sci. 5(8): 71-74. doi: http://dx.doi.org/10.20546/ijcmas.2016.508.008 